\title{
School Principal Leadership Behavior - A Multi Case Study
}

\author{
Zainal Ilmi *, Muhammad Saleh, Ahmad Muhyani Rizalie \\ Master Program of Education Management, Universitas Lambung Mangkurat, Banjarmasin 70123, \\ Indonesia
}

Article history:

Submission November 2019

Revised July 2020

Accepted July 2020

*Corresponding author:

E-mail: ilmi.zainal89@gmail.com

\begin{abstract}
Principal's leadership Behavior in educational institutions led to several changes in a multi-case study. The purpose of this research, therefore, is to describe the interpersonal communication, decision-making, exemplary, reward, and punishment Behavior of the School Principal. This study uses a qualitative approach with multi-case study design and purposive sampling, which continues to snowball sampling. Data validity techniques are through triangulation. The results showed that the interpersonal communication Behavior of principals leads to high work motivation, encourage teacher performance optimally, and creates a conducive learning climate. Principal's decision making is evident from the paternalistic leadership Behavior towards teachers, increasing self-confidence and improves the quality of human resources in the school. The exemplary behavior of the principal raises the attitude of discipline, fairness, and teacher responsibility, apart from creating making teachers creative and hardworking. Reward Behavior increases motivation for self-actualization, and the resolution of cases is carried out with a balance between the strictness of rules and humanitarian relations. This study implies that the interpersonal communication behavior of the principal at the Limbung Bay State Elementary School and Darul Falah Islamic Elementary School has been carried out effectively. Educational standards of an institution, in this case, can be seen from the work motivation given by the school principal and the cooperation established within the school community in the form of helping each other. Principal's decision-making behavior in both schools has been efficient and can be seen from the paternalistic leadership towards teachers in the class, which increases their level of confidence.
\end{abstract}

Keywords: Leadership behavior, principal

\section{Introduction}

The basic education in question is elementary schools such as SD / MI or equivalent. According to Suryosubroto (2002) states that primary schools are educational institutions that carry out six-year educational programs for children aged 6-12 years. This is in line with what was revealed by Fuad and Ihsan (2008) that elementary schools as a whole were carried out within a 6-year learning program. According to Sabdulloh and Uyoh (2010) that the School is an educational environment that is deliberately designed and implemented with strict rules such as having to be tiered and continuous so that it is called formal education and the school is a special institution, a vehicle, a place to organize education, in which there is a process of teaching and learning to achieve certain educational goals. As a manager of the school, the principal plays a vital role in improving the teaching mode. This assertion is in line with Mulyasa (2007), which states that the school principal is one of the most necessary components of education and helps in improving the quality of learning.

Therefore, the leadership adopted in the leading system has a significant influence on school management. Leadership is an important aspect a school principal needs to organize a group and achieve predetermined goals. In line with this, Suhaimi (2019) leadership is defined as influencing processes, which influence the interpretation of events for followers, and Wahjosumidjo (2007) stated that leadership is the process of influencing group activities to achieve goals. The intended purpose cannot be separated from the process and results of education, which are part of the 
quality. The intended purpose cannot be separated from the educational process and educational outcomes which are part of the quality of education itself. According to Karwati and Priansa (2015) the quality is a philosophy and methodology that helps institutions to plan changes and set the agenda in the face of excessive external pressures". Various obstacles in improving the quality of elementary school education cannot be separated from the issues related to quality, such as managerial eminence of leaders, teacher efficiency, curriculum relevance, funding accuracy, infrastructure, educational facilities, and the limited student interest.

This study is conducted at the basic education level since it is essential as a long-term investment in the development of quality human resources. The study is carried out on Teluk Limbung Elementary School and Darul Falah Islamic Elementary School. Teluk Limbung State Elementary School ran smoothly after implementing a leadership and renewal style. This drastic change occurred in a relatively short time after the management of quality improvement based on elementary schools. However, it was led by a professional and experienced principal.

Likewise, in Darul Falah Islamic Elementary School, the principal directed the time of admission to be 07.15. Students would first carry out the "Al-Quran" recitation, followed by the Dhuha prayer before the teaching and learning activities begin. Moreover, there are more unique calls for male and female teachers, referred to as Ustadz and Ustazah, respectively.

These educational institutions, with various similarities and differences, form the two research sites, already stated as cross-case or multi-cases. These include (l) case 1 Darul Falah Islamic Elementary School Sungai Tabukan District, and (2) case 2. Teluk Limbung State Elementary School Babirik District. While the management function according to Usman (2003) includes planning, implementation, supervision, and organization. This research is focused on the principal's leadership behavior in managing educational institutions. The purpose of this research is to describe the interper- sonal communication, decision-making, exemplary and reward, and punishment behavior of principals. The multi-case study is conducted to I conducted a multi-case study to get more detailed data, so that the description of the results of the research became clearer and more detailed. This is also driven by the desire to generalize the resulting concept or theory. In other words, the use of a large number of cases is intended to cover up the weaknesses contained in the use of a single case, which is considered to be generalizable.

\section{Material and Methods}

The research used a qualitative design. The main instrument was the researchers, along with interviews, observation, and documentation. It was conducted at the Darul Falah Islamic Elementary School in Tambak Street, no 05 Pematang Benteng Hilir Village Sungai Tabukan District North Hulu Sungai Regency and Teluk Limbung State Elementary School in Teluk Limbung street, no 03 Teluk Limbung Village Babirik District North Hulu Sungai Regency.

The sampling technique is used in two stages. First, a single case study in the first case used a purposive sampling technique. To obtain data with an adequate amount and quality in this study snowball sampling was used. Data collection techniques were carried out by participant observation, in-depth interviews, documentation. Data analysis techniques used in this study refer to the concept of Milles \& Huberman (1992), an interactive model that classifies data analysis in three steps, namely data reduction, data presentation (display data), and concluding (verification). Test data credibility or trust in the results of the research can be done with extended observations, increased perseverance, triangulation, discussions with colleagues, negative case analysis, and member check. Triangulation using sources, methods, and time. To achieve the value of data credibility in this research, researchers used data source triangulation techniques and methods, peer discussions, and consultations with supervisors. This research went through the stages as written by Moleong (2010), namely the pre- 
field stage, the stage of fieldwork, and the stage of data analysis, up to the research report.

\section{Results and Discussion}

Principal's interpersonal communication behavior

Principal's leadership in interpersonal communication behavior is conducted by involving both educators and educational staff in internal and external coaching, trying to be fair, always protecting teachers, and being friendly and attentive.
This is in line with Muhammad (2005) opinion which states that interpersonal communication is communication that forms relationships with others. These relationships can be classified in several ways including intimate interaction, interrogation social conversation, or examination and interviews. Therefore, teachers work together and follow ethical, spiritual values. The results of the case examination were followed by a cross-case analysis of each focus of the research (Table 1).

Table 1. Cross-Case Findings Regarding Principal's Interpersonal Communication Behavior

\begin{tabular}{|c|c|c|c|c|}
\hline No & $\begin{array}{c}\text { Principal's Interper- } \\
\text { sonal Communication } \\
\text { Behavior }\end{array}$ & Case7I & Case II & Conclusion \\
\hline 1 & Work motivation & $\begin{array}{l}\text { The given motivation } \\
\text { is related to high } \\
\text { spiritual values. The } \\
\text { principal always } \\
\text { tries to serve as } \\
\text { much as possible, for } \\
\text { example, in inspiring } \\
\text { teachers and then } \\
\text { convey them with } \\
\text { noble goals. } \\
\text { (observation, } \\
\text { interview) }\end{array}$ & $\begin{array}{l}\text { Spiritual values are } \\
\text { accustomed to the } \\
\text { teachers. Therefore, } \\
\text { they work sincerely } \\
\text { to obtain the goals } \\
\text { of the school and } \\
\text { the teacher. .(obser- } \\
\text { vation, interview) }\end{array}$ & $\begin{array}{l}\text { The work motivation of } \\
\text { the principals in two } \\
\text { cases contained spir- } \\
\text { itual values and was } \\
\text { conveyed with the noble } \\
\text { purpose of obtaining } \\
\text { school and work perfor- } \\
\text { mance. }\end{array}$ \\
\hline 2 & Teacher Collaboration & $\begin{array}{l}\text { The principal also } \\
\text { helps the teachers to } \\
\text { be able to cooperate } \\
\text { and help each other } \\
\text { in carrying out tasks. } \\
\text { (observation, } \\
\text { interview) }\end{array}$ & $\begin{array}{l}\text { The head teacher } \\
\text { fosters a high sense } \\
\text { of cooperation for } \\
\text { the progress of the } \\
\text { school. Teachers } \\
\text { help each other in } \\
\text { completing work at } \\
\text { school. } \\
\text { (observation, } \\
\text { interview) }\end{array}$ & $\begin{array}{l}\text { Collaboration in both } \\
\text { cases is considered good } \\
\text { since the principal in- } \\
\text { stills cooperative behav- } \\
\text { ior in teachers to com- } \\
\text { plete work at school. }\end{array}$ \\
\hline
\end{tabular}

\section{Principal's Decision-making behavior}

Principal's decision-making behavior involves building excellent communication, intensely in order informational bond, and deliberate on matters. This is in line with the opinion of Siswanto (2015) who said that decision mak- ing is a series of activities carried out by someone to solve the problem being faced then set various alternatives that are considered most rational following the environment. The case analysis was followed by a cross-case of each focus of the research, as follows. 
Table 2. Cross-Case Findings Regarding Principal Decision Making Behavior

\begin{tabular}{|c|c|c|c|c|}
\hline No & $\begin{array}{l}\text { Principal's decision- } \\
\text { making behavior }\end{array}$ & Case I & Case II & Conclusion \\
\hline 1 & $\begin{array}{l}\text { Helps overcome Stu- } \\
\text { dent Problems in } \\
\text { Classroom Learning }\end{array}$ & $\begin{array}{l}\text { Responds to all } \\
\text { problems quickly, } \\
\text { both in teachers' and } \\
\text { students' cases. } \\
\text { (interview) }\end{array}$ & $\begin{array}{l}\text { It helps the teacher by di- } \\
\text { recting and dislike when } \\
\text { there is an issue that is } \\
\text { not immediately handled. } \\
\text { (interview) }\end{array}$ & $\begin{array}{l}\text { Addresses the } \\
\text { problem affect- } \\
\text { ing students } \\
\text { quickly and of- } \\
\text { fer direct coach- } \\
\text { ing. }\end{array}$ \\
\hline 2 & $\begin{array}{l}\text { Give confidence to } \\
\text { educators and educa- } \\
\text { tional staff in terms } \\
\text { of the delegation of } \\
\text { tasks }\end{array}$ & $\begin{array}{l}\text { Gives confidence to } \\
\text { teachers who are } \\
\text { deemed capable of } \\
\text { carrying out their } \\
\text { duties. (observation, } \\
\text { interview) }\end{array}$ & $\begin{array}{l}\text { Identifies the abilities of } \\
\text { each teacher; therefore, } \\
\text { the principal delegate } \\
\text { tasks appropriately. (ob- } \\
\text { servation, interview) }\end{array}$ & $\begin{array}{l}\text { From the two } \\
\text { cases, the prin- } \\
\text { cipal gives the } \\
\text { same confidence } \\
\text { to the teachers } \\
\text { by first identify- } \\
\text { ing their abili- } \\
\text { ties and then } \\
\text { make the right } \\
\text { decision in dele- } \\
\text { gating tasks. }\end{array}$ \\
\hline 3 & $\begin{array}{l}\text { Improve the ability } \\
\text { of teachers }\end{array}$ & $\begin{array}{l}\text { Enhances the ability } \\
\text { of the teacher } \\
\text { through comparative } \\
\text { studies, examining } \\
\text { the linearity of the } \\
\text { educator's diploma, } \\
\text { holding discussions, } \\
\text { completing support- } \\
\text { ing books, and in- } \\
\text { creasing teacher fi- } \\
\text { nances. (interview) }\end{array}$ & $\begin{array}{l}\text { Involves the teacher in } \\
\text { training from outside the } \\
\text { school and direct guid- } \\
\text { ance. (interview) }\end{array}$ & $\begin{array}{l}\text { In both cases, } \\
\text { the principal at- } \\
\text { tempted to im- } \\
\text { prove the qual- } \\
\text { ity of Human } \\
\text { Resources to } \\
\text { optimize the } \\
\text { ability of teach- } \\
\text { ers. }\end{array}$ \\
\hline
\end{tabular}

\section{Principal's exemplary behavior}

Exemplary Behavior Principals always work hard by utilizing all their abilities to improve the quality and progress of the school. This is in line with Ishlahunnissa (2010) exemplary means planting morals, manners, and good habits that should be taught and familiarized by giving concrete examples. Exemplary education is the approach or method that influences and is proven to be the most successful in preparing and shaping and developing potential. Additionally, they try to explore the potential of teachers, students, and the community to work together to achieve the expected goals. Principals in the eyes of teachers are intelligent, good at dealing with problems, responsive to circumstances, disciplined, often setting an example to others, creative, and hardworking. Findings on aspects of the principal's role model in the two cases are described (Table 3). 
Table 3. Cross-Case Findings Regarding The Exemplary Behavior of School Principals

\begin{tabular}{|c|c|c|c|c|}
\hline No & $\begin{array}{l}\text { Principal's Exem- } \\
\text { plary Behavior }\end{array}$ & Case I & Case II & Conclusion \\
\hline 1 & $\begin{array}{l}\text { Grow high commit- } \\
\text { ment }\end{array}$ & $\begin{array}{l}\text { The school principal and } \\
\text { teachers have a high com- } \\
\text { mitment to improving the } \\
\text { quality of the school. This is } \\
\text { seen in the daily atmos- } \\
\text { phere of the school. The } \\
\text { presence of the principal of } \\
\text { the school makes the envi- } \\
\text { ronment conducive. The } \\
\text { teachers remain orderly } \\
\text { and disciplined. (observa- } \\
\text { tion, interview) }\end{array}$ & $\begin{array}{l}\text { The school principal ad- } \\
\text { vises noble goals of disci- } \\
\text { pline and responsibility } \\
\text { everywhere, then ex- } \\
\text { presses her gratitude to } \\
\text { the teachers who have } \\
\text { been disciplined to get } \\
\text { used to and show high } \\
\text { commitment. (observa- } \\
\text { tion, interview) }\end{array}$ & $\begin{array}{l}\text { The principal ac- } \\
\text { customs the } \\
\text { teacher to have a } \\
\text { high commitment } \\
\text { to the task as a } \\
\text { teacher. Therefore, } \\
\text { the atmosphere of } \\
\text { the school will look } \\
\text { conducive, orderly, } \\
\text { and disciplined. }\end{array}$ \\
\hline 2 & $\begin{array}{l}\text { Principal's Exem- } \\
\text { plary }\end{array}$ & $\begin{array}{l}\text { The principal always does } \\
\text { the work, producing results, } \\
\text { has new ideas, and is re- } \\
\text { sponsive to circumstances, } \\
\text { and serves as a leader who } \\
\text { is disciplined in managing } \\
\text { time. (observation, } \\
\text { interview, documentation) }\end{array}$ & $\begin{array}{l}\text { Principals are perceived } \\
\text { as intelligent people, } \\
\text { good at dealing with } \\
\text { problems, responsive to } \\
\text { circumstances, disci- } \\
\text { plined, always setting an } \\
\text { example to teachers, cre- } \\
\text { ative, hardworking. } \\
\text { (observation, interview, } \\
\text { documentation) }\end{array}$ & $\begin{array}{l}\text { From both cases, it } \\
\text { is evident that prin- } \\
\text { cipals in the two } \\
\text { schools set good ex- } \\
\text { amples for their } \\
\text { teachers. }\end{array}$ \\
\hline 3 & $\begin{array}{l}\text { Principal's manage- } \\
\text { ment ability }\end{array}$ & $\begin{array}{l}\text { The ability possessed by the } \\
\text { principal to lead the school } \\
\text { is indeed efficient. This is } \\
\text { because the principal of the } \\
\text { Darul Falah Islamic Elemen- } \\
\text { tary School is a leader with } \\
\text { the advantage of leading the } \\
\text { school community. } \\
\text { (interview) }\end{array}$ & $\begin{array}{l}\text { The ability of the princi- } \\
\text { pal to manage is indeed } \\
\text { critical. The principal of } \\
\text { the Teluk Limbung State } \\
\text { Elementary School } \\
\text { succeed in managing the } \\
\text { institution; as a result, } \\
\text { others learned manage- } \\
\text { ment from the school. } \\
\text { (interview) }\end{array}$ & $\begin{array}{l}\text { The two cases show } \\
\text { that the abilities of } \\
\text { principals are in- } \\
\text { deed not questiona- } \\
\text { ble, and have vari- } \\
\text { ous advantages. }\end{array}$ \\
\hline
\end{tabular}

\section{Reward and punishment behavior}

Reward and punishment behavior involve giving awards to outstanding teachers. It is not in the form of goods and money, but rather by expressing gratitude to them. Every teacher is also subjected to punishment when making mistakes by always being rebuked and advised and even summoned in other teacher committee meetings. This is in line with the understanding of rewards themselves, namely rewards, prizes, awards, or rewards that aim to make someone more active in their efforts to improve or improve performance that has been achieved (Thoha \& Miftah, 2004). Whereas punishment according to Mangkunegara (2013) is a threat of punishment aimed at improving the performance of violating employees, maintaining applicable regulations, and giving lessons to violators. This is intentionally carried out by the school principal, and as a result, the other teachers do not make the same mistakes. Findings on behavioral aspects of reward and punishment in the two cases are described (Table 4). 
Table 4. Cross-Case Findings Regarding Reward And Punishment Behavior

\begin{tabular}{|c|c|c|c|c|}
\hline No & $\begin{array}{c}\text { Reward and Punishment } \\
\text { Behavior }\end{array}$ & Case I & Case II & Conclusion \\
\hline 1 & $\begin{array}{l}\text { Appreciating Teacher } \\
\text { Performance }\end{array}$ & $\begin{array}{l}\text { Teachers who do their job } \\
\text { well are given a reward } \\
\text { from the principal or di- } \\
\text { rect praise, as motivation. } \\
\text { For instance, the principal } \\
\text { gives direct praise or bias } \\
\text { announced at the Monday } \\
\text { morning ceremony. } \\
\text { (interview) }\end{array}$ & $\begin{array}{l}\text { Educators or educa- } \\
\text { tional staff who per- } \\
\text { form their duties } \\
\text { properly are given di- } \\
\text { rect praise from the } \\
\text { principal, as a result } \\
\text { motivating them. } \\
\text { (interview) }\end{array}$ & $\begin{array}{l}\text { The award given to } \\
\text { outstanding teachers is } \\
\text { not in the form of } \\
\text { goods and money, but } \\
\text { by expressing grati- } \\
\text { tude. The award is in- } \\
\text { tended to motivate } \\
\text { teachers. }\end{array}$ \\
\hline 2 & $\begin{array}{l}\text { Give punishment for } \\
\text { teacher's mistakes }\end{array}$ & $\begin{array}{l}\text { Teachers who make mis- } \\
\text { takes are usually called in } \\
\text { the office and advised } \\
\text { later in the meeting. As a } \\
\text { result, the same mistakes } \\
\text { do not occur. (interview) }\end{array}$ & $\begin{array}{l}\text { The teacher who made } \\
\text { a mistake, the princi- } \\
\text { pal responded very } \\
\text { quickly by calling the } \\
\text { teachers who violated } \\
\text { it, then talked to them, } \\
\text { and a meeting would } \\
\text { be held to discuss the } \\
\text { incident. (interview) }\end{array}$ & $\begin{array}{l}\text { Every teacher who } \\
\text { makes a mistake is al- } \\
\text { ways reprimanded and } \\
\text { advised and even sum- } \\
\text { moned in other } \\
\text { teacher committee } \\
\text { meetings. This is inten- } \\
\text { tionally conducted for } \\
\text { other teachers not to } \\
\text { make the same mis- } \\
\text { takes. Therefore, } \\
\text { teachers are always } \\
\text { careful in acting and } \\
\text { carrying out their du- } \\
\text { ties. }\end{array}$ \\
\hline 3 & $\begin{array}{l}\text { Supervision of the Prin- } \\
\text { cipal }\end{array}$ & $\begin{array}{l}\text { The principals usually go } \\
\text { directly to the classroom } \\
\text { without informing the } \\
\text { teachers in advance, fol- } \\
\text { lowing the lessons in } \\
\text { them directly. In case } \\
\text { there is something wrong, } \\
\text { they are advised (to } \\
\text { build). (interview) }\end{array}$ & $\begin{array}{l}\text { The principal moni- } \\
\text { tors from outside the } \\
\text { classroom for supervi- } \\
\text { sion. If there is a mis- } \\
\text { take, the teacher is } \\
\text { called to the office for } \\
\text { a moment to be ad- } \\
\text { vised. The principal } \\
\text { helps to correct the } \\
\text { matter without blam- } \\
\text { ing the teacher. } \\
\text { (interview) }\end{array}$ & $\begin{array}{l}\text { Supervision conducted } \\
\text { by the principal in } \\
\text { these cases is not } \\
\text { scheduled, meaning } \\
\text { that it can be anytime } \\
\text { and anywhere. As a re- } \\
\text { sult, the teacher al- } \\
\text { ways prepares well } \\
\text { and teach optimally. }\end{array}$ \\
\hline
\end{tabular}

Table 5. The cross-case findings

1. Principal's Interpersonal Communication Behavior

P.1.1. High work motivation given encourages teacher performance.

P.1.2. Cooperation established within the school community in the form of help and assistance creates a conducive learning climate.

2. Principal's decision-making behavior

Continued.... 
P.2.1 Paternalistic leadership behavior towards the teacher in the class increases self-confidence.

P.2.2. The principal gives a delegation of tasks according to the teacher's ability to improve performance.

P.2.3. Principals improve the quality of existing Human Resources by directly coaching or attending training, enhancing teacher competency.

3. Principal's Exemplary Behavior

P.3.1. Coaching the teacher's commitment leads to discipline, fair behavior, and teacher responsibility.

P.3.2. Principals having exemplary behavior makes teachers creative and hard-working.

P.3.3 Principal's managerial ability to improve the quality of the school or institution.

4. Reward and Punishment Behavior

P.4.1. The reward system increase motivation for self-actualization.

P.4.2. Resolving cases of problematic teachers is performed with a balance between the strictness of regulations and humanitarian relations, making teachers loyal and dedicated.

P.4.3. Supervision by the principal by assessing will increase teacher professionalism in teaching.

\section{Conclusion and Recommendation}

The interpersonal communication behavior of the principal at the Limbung Bay State Elementary School and Darul Falah Islamic Elementary School has been carried out effectively. Educational standards of an institution, in this case, can be seen from the work motivation given by the school principal and the cooperation established within the school community in the form of helping each other. Principal's decision-making behavior in both schools has been efficient and can be seen from the paternalistic leadership towards teachers in the class, which increases their level of confidence.

The exemplary behavior of the principals in both schools is following the characteristics of the exemplary figures set Reward and punishment behavior in both institutions is critical. For more effectiveness, this study makes several recommendations. To overcome interpersonal communication problems, there is a need to increase work motivation and teacher cooperation with persuasive approaches to various parties in making decisions with role models. This might make the school environment conducive, improve its quality, provide rewards for outstanding teaching staff, and uphold professionalism. Punishment also needs to be continued and given according to the problem the teachers face. The Office of Education and the Ministry of Religion needs to be improved to foster the leadership behavior of school principals. Also, the research on the Principal's Leadership Behavior (Multi-Case Study at Darul Falah Islamic Elementary School and Teluk Limbung State Elementary School, North Hulu Sungai Regency) can be beneficial for the development of thought treasures and studies on leadership orientation based on educational institutions.

\section{Acknowledgment}

The author would like to thank you for supporting this research especially the beloved family, and Education Management Master Program, Universitas Lambung Mangkurat.

\section{References}

Ihsan, \& Fuad. (2008). Dasar-dasar kepemimpinan. Bandung: Rineka Cipta Press.

Ishlahunnisa. (2010). Mendidik anak perempuan. Solo: PT. Aqwam Media Profetika.

Karwati, E., \& Priansa, D. J. (2015). Manajemen kelas, guru profesional yang inspriratif, kreatif, menyenangkan dan berprestasi. Bandung: Alfabeta.

Mangkunegara, A. A. (2013). Manajemen sumber daya manusia perusahaan. Bandung: Remaja Rosdakarya.

Miller, M., \& Huberman. A. M. (1992). Qualitative data analisis. Beverly Hills: Sage Publication,Inc.

Moleong, L. J. (2010). Metode penelitian kualitatif. Bandung: Remaja Rosdakarya. 
Muhammad, A. (2005). Komunikasi organisasi. Jakarta: Bumi Aksara.

Mulyasa. (2007). Menjadi guru profesional menciptakan pembelajaran kreatif dan menyenangkan. Bandung: Rosdakarya.

Sabdulloh, \& Uyoh. (2010). Pedagogik ilmu mendidik. Bandung: Alfabeta.

Siswanto. (2015). Manajemen tenaga kerja. Bandung: Sinar Baru. Suhaimi. (2019). Kepemimpinan pendidikan. Malang: CV IRDH.
Suryosubroto. (2002). Proses belajar mengajar di sekolah. Jakarta: Rineka Cipta.

Thoha, \& Miftah. (2004). Kepemimpinan dalam manajemen. Jakarta: Pt. Raja Grafindo Persada.

Usman, U. (2003). Menjadi Guru Profesional. Bandung: PT. Remaja Rosda Karya.Wahjosumitjo. (2007). Kepemimpinan kepala sekolah, tinjauan teoritik dan permasalahannya. Jakarta: PT. Raja Grafindo Persada. 
